\title{
4
}

\section{Should I Stay or Should I Go? Hunter-Gatherer Networking Through Bilateral Kin}

\author{
Russell D. Greaves and Karen L. Kramer
}

\section{Introduction}

Mobility and shifting kin associations structure a range of subsistence, sharing, and cooperative support networks in traditional human societies. Both traditional ethnographic interests in familial alliance and behavioural ecology's comparative focus view postmarital residence as fundamental in determining kin associations and group composition. Despite the long history of interest in environmental and behavioural factors that influence postmarital residence, results from cross-cultural research differ in their characterisation of predominant patterns and causal relationships between environment, social organisation, coalitionary activities, and residence (Ember 1978; Ember and Ember 1971, 1972; Marlowe 2004; Otterbein and Marlowe 2005; Quinlan and Quinlan 2007; Rodseth et al. 1991).

In the spirit of Harold Scheffler's perspective that kinship stems from biological relatedness (Scheffler 2001), we see the interactions between individuals in Pumé forager communities to be constructed primarily according to genetic distance and secondarily through self-interested participation in cooperative subsistence efforts. We support the view that facultative adaptations of kinship systems are always based in recognition 
that they primarily derive from and describe genealogical kinship. Kinship classifications are not cultural constructs unrelated to descent and genetic kinship as has been suggested by Schneider (1972, 1984). The extension of these biological terms as facultative kin (that fictively assign individuals' relationships beyond their actual genetic relationship to others) creates relationships that are then subject to behavioural and social expectations determined by the roles of biological kin. Far from denying the importance of descent, such facultative links use biology to structure the many uniquely human cooperative behaviours in relation to the kinds of self-interested interactions of both close and distant kin. Living with an array of recognised close and more distant kin is one way that humans structure the cooperative behaviours that are central to our species' unique adaptations. Our perspective in this chapter looks at the advantages that bilateral kinship systems have in providing maximally extensive familial support networks for hunter-gatherer adaptations. This longitudinal study of camp associations among mobile, foraging Pumé of Venezuela permits investigation of how long-term residential patterns compare with other hunter-gatherer groups living in contrasting environments.

\section{Hunter-gatherer residence}

Distinguishing how humans use kin associations may also help understand how human life history and complex cooperative behaviours evolved as distinct and highly successful strategies. One important source of these cooperative activities is through elective membership in a community that provides alliances and fall-back options based on kinship. In many group-living animals, including primates, individuals emigrate at sexual maturity and join new communities. Dispersal patterns lay much of the foundation for sociality and are important in the formation of both kin and nonkin associations. In humans much debate has surrounded postmarital residence and identifying whether a single pattern typifies hunter-gatherers. While human dispersal was traditionally portrayed as being male-biased, the model of the patrilocal band (Radcliffe-Brown 1930; Service 1962; Steward 1955) has long been questioned (Ember 1975; Helm 1965; Hiatt 1962; Lee 1972, 1979; Lee and DeVore 1968; Meggitt 1965; Murdock 1949; Shapiro 1973; Turnbull 1965). Matrilocality generally has been considered less prevalent among huntergatherers (Walker et al. 2013) and is associated with particular activities resulting in male absenteeism, such as external warfare (Divale 1974; 
Ember and Ember 1971), long distance hunting (Perry 1989) and reliance on female subsistence (Scelza and Bliege Bird 2008). A number of recent case studies have pointed out that residence patterns among foragers are flexible, facultative and may vary across the life course (Blurton Jones et al. 2005; Marlowe 2010). Several recent cross-cultural studies that synthesise much of the comparative data on hunter-gatherers have highlighted the importance of bilocal and multilocal residence (Alvarez 2004; Costopoulos 2005; Gray and Costopoulos 2006; Kelly 1995; Marlowe 2004, 2005). The results from these general analyses dispute many earlier expectations that most hunter-gatherers can be characterised by sex-biased postmarital residence (Cavalli-Sforza 1997; Ember 1978; Ember and Ember 1971; Rodseth et al. 1991) and are a provocative contrast to traditional perceptions of hunter-gatherer social organisation.

\section{Cross-cultural studies}

While cross-cultural studies are critical to uncovering large-scale patterning, they also have limitations. The cross-cultural databases are derived from ethnographies in which postmarital residence classifications are taken primarily from interviews and culturally stated marriage rules rather than from observation. These norms often do not account for intragroup variation in postmarital residence that arises to cope with diverse environmental and demographic conditions in traditional societies. Informants often describe current conditions that may not include temporal histories or account for lifetime changes in residence. Because cross-cultural comparisons depend on aggregate data, they necessarily overemphasise cultural norms and underrepresent both individual and group variation. The coding of ethnographic case studies for use in standard comparative samples (Binford 2001; Murdock 1949; Murdock and White 1980) involves further abstraction from sources that contain inherent differences in data collection methods, thoroughness of ethnographic observation and other sampling idiosyncrasies.

To balance the challenges posed by cross-cultural comparisons, longitudinal and individual-level data provide an important temporal view on marriage dynamics at a time depth unavailable in aggregate comparisons. They also are able to capture variability in postmarital residence arrangements both within groups and across the life course. 
The combination of large-scale comparisons across multiple societies with focused individual-level longitudinal data is crucial in reexamining hunter-gatherer social organisation.

In this chapter we compare postmarital residence patterns among mobile Pumé foragers of Venezuela in order to investigate the prevalence of sexbiased and nonsex-biased residence using detailed data spanning 25 years. We first situate the problem of postmarital residence and discuss why we expect bilateral kin networks to be key for mobile hunter-gatherers. Analyses using the longitudinal Pumé data demonstrate a strong residence pattern of natolocality. The discussion turns to environmental influences on residence patterns and how different hunter-gatherer mobility can accomplish similar ends in maximising bilateral kin affiliations compared to sex-biased residence. The Pumé example emphasises ways that men and women may strategise opportunities to retain extended kin access in the face of stochastic demographic variation in a small-scale foraging society.

\section{Human dispersal and postmarital residence}

\section{Historical background}

Humans exhibit a broad range of dispersal and postmarital residence patterns. This is reflected in the rich anthropological terminology describing residential affiliations, social assortment options and the obligations and opportunities they provide. While many aspects of reproductive behaviour have become important areas of human behavioural ecology research (Rodseth et al. 1991), kinship and residence studies have languished with less attention. Although a range of huntergatherer behaviours formerly characterised as determined by static cultural norms (i.e. sharing, marriage, cooperation) have been reevaluated using behaviour observation methods, perspectives on residence patterns have remained within the grip of assumed conformity with normative practice.

Early hunter-gatherer studies (Radcliffe-Brown 1930; Service 1962, 1966) and some kinship studies appealed to by researchers seeking broad crosscultural regularities among all hunter-gatherer populations (i.e. LéviStrauss 1949) emphasised patrilocal organisation as the dominant form of social organisation that structured territoriality and exogamous marriage. Interest in modern hunter-gatherers during the 1960s challenged this 
assumption and recognised that many groups maintain very flexible social organisation that emphasises association with bilateral kin (Helm 1965; Hiatt 1962; Lee and Devore 1968; Turnbull 1965). More recent crosscultural surveys emphasise the importance of multilocality rather than sex-biased dispersal among hunter-gatherers. Unfortunately the exchanges (Costopoulos 2005; Gray and Costopoulos 2006; Marlowe 2005; Otterbein and Marlowe 2005) following Frank Marlowe's (2004) crosscultural study of postmarital residence focused on sampling and the use of the Standard Cross-Cultural Sample, rather than on his demonstration of the predominance of multilocality among foragers. Marlowe's approach is a valuable way to try and extract the dynamics of residential variation from data collected under assumptions of strict and static cultural norms of residential behaviour.

Despite these reanalyses, patrilocality remains a common characterisation of foragers (Cant and Johnstone 2008; Cavalli-Sforza 1997; Di Fiore and Rendall 1994; Ember 1975, 1978; Otterbein and Marlowe 2005; Rodseth et al. 1991). For example, a number of recent genetic studies that address residence patterns assume that patrilocality is common among huntergatherers. Patterns of sex-biased dispersal appear evident based on greater diversity in mtDNA compared with low variance in Y-chromosome expression (Destro-Bisol et al. 2004a; Oota et al. 2001; Seielstad et al. 1998). Some results are ambiguous (Langergraber et al. 2007; Kumar et al. 2006; Wilder et al. 2004) and interpretations of patrilocality may not consider whether potentially highly differential male reproductive success compared to lower female variance could produce similar patterns (however, see Destro-Bisol et al. 2004a).

While kin often are implicated in these interactions (food sharing, cooperation, allocare, resource and labour transfers), few quantitative data are available for postmarital residence patterns that form the basis of these kin associations. Among any foraging population, longitudinal observational data are necessary to capture both the variation in camp memberships and long-term kin associations that can be evaluated as potential strategies of cooperation with relatives. Although interview questioning can elicit stated preferences for matrilocal or patrilocal residence, it is unclear whether this supports the concept of cultural norms or describes situational and variable kin associations. We feel that greater time investment is needed to collect empirical data on residential patterns. 


\section{Bilateral kin networks}

Comparative data suggest that many foraging societies practise situational flexibility in the kin with whom an individual or family lives (Alvarez 2004; Marlowe 2004). Viewed from both male and female perspectives, a residence pattern that maintains access to bilateral kin is advantageous in many ways. In the absence of compelling reasons to associate more closely with virilocal or uxorilocal kin, or for one sex to preferentially disperse from their natal communities, bilocal residence creates the broadest base of potential kin interaction for mobile foragers. In addition to providing opportunities for interactions with parents of both husband and wife, bilaterality broadens access to collateral kin-siblings, in-laws, cousins, nieces, nephews, and other more distant kin referent to both members of the couple (Silberbauer 1972). While in some societies close association with certain kin may augment potential conflicts (between brothers, or sisters, or in reference to downwardly directed resources from wives' or husbands' parents), there is no a priori reason to expect that conflict is a more important determinant of residence than opportunities for cooperation.

In some societies, preferred lineality is an important means of recruiting or obliging particular kin to cooperate (Alvard 2003; Alvard and Nolin 2002). Because lineality incorporates individuals beyond closely related kin (Dunbar 2008), it can bring large numbers of individuals together where certain tasks require articulation of larger work groups or material capital than a nuclear or extended family can muster (Donald 1997; Kan 1989; Mauss 1967; Oberg 1973). This is pertinent in large village communities, with greater resident populations than are represented by most mobile foragers' camps. In small-scale populations with smaller or changing resident membership, preferred lineality would limit the number of potential collaborators whereas bilaterality is maximally inclusive of kin (Alvard 2002; Ember 1975). This is one reason why the characterisation of hunter-gatherers as predominantly patrilineal or matrilineal has been challenged (Blurton Jones et al. 2005; Hiatt 1962; Lee 1972, 1979; Marlowe 2004, 2010; Scelza and Bliege Bird 2008; Turnbull 1965; Woodburn 1972).

The flexibility of bilateral residential organisation may be especially important in small-scale societies where stochastic variation in birth and survivorship can result in skewed age and sex distributions (Ember 1975). For example, between 1990 and 1993, in one Savanna Pumé community 
short-term asymmetries in birth and survival rates resulted in four boys between the ages of zero and seven, in contrast to 17 girls between these same ages (Greaves 1997a). Bilateral residence options permit a facultative means to adjust uneven age and sex ratios, either to balance production and consumption ratios or to facilitate mating opportunities. Maximising rather than biasing potential kin association may be especially relevant for foraging economies where subsistence often changes throughout the year, and oscillations in residential organisation can respond to changes in labour organisation and sharing patterns.

Bilateral kin affiliation also can permit greater potential flexibility in residence. In many groups of hunter-gatherers, parents and other relatives help support young couples, who may not yet be mature food producers (Bogin 1999; Hrdy 2005; Kaplan 1996; Kramer 2008; Kramer and Greaves 2010; Kramer, Greaves and Ellison 2009). Rather than restricting access to kin, bilateral association can make it possible for couples to situationally locate with the kin of either spouse in response to demographic changes in family composition. Parents also are expected to be self-interested in maintaining potential relationships with both their sons and daughters. Parents may manipulate the potential mate pools for their children by choosing residences with the highest number (or value) of potential mates. These examples are far from exhaustive, but they illustrate the benefits of bilateral kin associations. It is not clear whether multilocal residential organisation causes such flexibility or reflects extant practices. However, situationally responsive kinship options in relation to subsistence, marriage, or labour can provide hunter-gatherers with more diverse means of confronting environmental variability. In the Lamalera example (sedentary Indonesian fisher-traders) a large population is required to maintain diverse roles within a unilineal system that structures food access through stringently fixed rules of participation and rewards (Alvard 2003; Alvard and Nolin 2002). Such conditions are rarely encountered in small populations of hunter-gatherers (Alvard 2002).

Given the potential benefits of residential flexibility in small-scale foraging populations, we test the prediction that Pumé postmarital residence will be minimally sex-biased. Although early ethnographic descriptions identified the Pumé as generally matrilocal (Leeds 1964; Mitrani 1975, 1988; Orobitg Canal 1998; Petrullo 1939), we anticipate that sex-biased residence will be less common than bilateral association. The Pumé are mobile foragers. In contrast to known associations with sex-biased residence, the Pumé have a general equality of male and female dietary 
contributions, food excesses are uncommon, long-distance hunting is rare, opportunities for heritable property or status are minimal; there is no evidence of coercion or violence toward women and no institutional aggressive conflicts with other Pumé or non-Pumé. Additionally, the Pumé live in small groups of four to 13 extended families and are subject to stochastic variation in age and sex distribution. Given these conditions, we expect that bilateral affiliations will be maintained either through multilocal or natolocal postmarital residence.

\section{Methods}

\section{Study population}

The Pumé are indigenous to the low plains, or llanos, in the western portion of the Orinoco basin of west central Venezuela. Recent indigenous census figures from Venezuela (INE 2001, 2011) significantly over count many native groups because of changing recognition of indigenous rights following constitutional changes under the Chavez regime. We focus on the Savanna Pumé, who are mobile foragers with an estimated population of 800 individuals (Gragson 1989; Greaves 1997a, 1997b, 2006). The Savanna Pumé are a subset of the much larger Pumé ethnic and language group (OCEI 1985: 38, 1995: 32), which also includes sedentary horticultural villages and more acculturated towns. The Pumé linguistically recognise these three subsistence distinctions in their population.

The llanos are an extensive hyper-seasonal savanna, with approximately 85 per cent of the annual precipitation falling in the wet season from June to November. These grasslands are associated with very low diversity and densities of terrestrial fauna. Extreme rainfall variation dramatically alters the flora and fauna during each season. The wet season is associated with low protein returns (mean $=2 \mathrm{~kg} / \mathrm{hunter} / \mathrm{trip}$ ), substantial reliance on wild tubers (mean $=12 \mathrm{~kg} /$ woman/trip) and small inputs of cultivated manioc. Food availability increases during the dry season when men focus on aquatic resources. Although the mean fishing returns per trip are similar to hunting, more men fish each day, some men fish every day, multiple fishing trips by individuals are common on some days, and most boys contribute equivalent returns to adult efforts from this low-skill foraging activity. Tubers also are an important dry season food. Women, 
and a few men, collect large amounts of feral mangos (mean $=27 \mathrm{~kg} /$ woman/trip). Both male and female-contributed foods are critical to the diet and widely shared.

The Savanna Pumé move residential camps throughout the year in response to seasonal subsistence and variation in water availability. For example, Russell Greaves followed 11 main camp moves over 24 months between 1990 and 1993 (Greaves 1997a) and we identified six main residential moves for the same community over the 12 -month period of the dry season of 2004 through the dry season of 2005. Camp moves are associated with changes in the spatial configuration of houses and members within the community. Despite these frequent changes in family and individual distributions across different camps, the overall camp population remains quite stable. Small groups of individuals may leave these residential camps and establish temporary camps for a few days to a couple of weeks for focused subsistence activities or raw material exploitation. Small, short-term fishing camps are particularly common during the dry season. Temporary camps can include both spouses' kin, less closely related individuals with close subsistence or labour relationships, or other opportunistic arrangements. Membership in these temporary camps had few regular associations, except that husbands and wives always accompany each other. While we refer to these small, shortterm camps in the discussion, we use the residence patterns of the main camps from each of the two seasons for the purpose of the analyses.

\section{Pumé kinship}

The Pumé language (Pumé mai) is usually considered to be a language isolate (Mosonyi 1975; Obregón Muñoz 1981; Perez de Vega 1960). It may have been related to the now extinct Esmeralda or Otomaco languages (Hervás y Panduro 1979; Leeds 1964; Loukotka and Wilbert 1968), but it is completely unrelated to the Guahiboan (Arawak) languages of the dominant ethnic groups of the Venezuelan and Colombian llanos. Some linguists have suggested that Pumé may be classified as macro-Chibchan (Key 1979; Loukotka and Wilbert 1968; Tovar and Tovar 1961), Jivaroan (Key 1979), or might be similar to some Andean languages (Key 1979). Most discussions of the language affiliation of Pumé are simply repeating earlier classifications (de Carrocera 1980; Rey Fajardo 1979; Perez de Vega 1960). Vincenzo Petrullo (1939) erroneously reported the existence of moieties, a point refuted by Anthony Leeds 
(1964). Philippe Mitrani (1988: 188-95, tabla 2, figuras 1-3) presents the clearest outlines of Pumé kinship as reported by horticultural River Pumé. These terms are not very different from those employed by the hunting-and-gathering Savanna Pumé. Most researchers (excepting Gragson and Greaves) have only reported kinship terminology as a static descriptive system, but have not had opportunities to study nuances of its use. This is because investigators did not conduct their research using the Pumé language and spent little time in the field. All information about Pumé kinship terminology presented in this paper is based on research performed solely in the Pumé language over the 30 months of cumulative fieldwork.

Pumé kinship has been identified as bifurcate merging (Mitrani 1988), a Dravidian form of Dakota-Iroquois classification with some additional generational distinctions of ego's grandparents referent to parental sex. Dravidian systems are associated with kinship that is not matrilineal or patrilineal among indigenous Venezuelan populations including the Pumé, although this is not universal in other parts of South America (J. Shapiro 1984). The Pumé also distinguish birth-order age differences among siblings and parallel cousins that permit checking of relative ages within our samples. They do not recognise lineages, clans, or moieties (Leeds 1964).

The extension of Pumé kinship terms to parents' same-sex siblings does not indicate unilineal descent, as Warren Shapiro (1995) has demonstrated. As has been noted for many traditional societies (Scheffler 1970, 1972, 1973; Shapiro 2008 Chapter 1), the Pumé apply the term 'true' or 'real' (tamó) to distinguish biological mothers and fathers from parallel uncles and aunts, to name full and half siblings as distinct from parallel cousins, and to discriminate parents' biological children from parallel nieces and nephews. The qualifier is rarely applied to distinguish close biological kin such as aunts and uncles (or other ascendant or descendant relatives) who are siblings of parents from those of more distantly related individuals who share merged kinship-term designations.

Kinship is the crucial description of social relationships among the Pumé. The Pumé only use kin terms to address each other. No indigenous names or nicknames were encountered in our work with the Savanna Pumé. Names of adults are used only for interactions with outsiders. They are derived from Pumé adaptations of Spanish names, but the Pumé do not use Spanish or indigenous surnames. Among the Savanna Pumé, only kin 
terms are employed both within the community and in reference to the normal spheres of interactions with individuals in other communities. Only men and women who are rarely encountered (less than once every few years) are occasionally referred to by both their kin term and Spanish names for clarification. Pumé use names only in reference to children under the ages of approximately 11 years. We believe this is because the kin terms for nephews, nieces and grandchildren contain minimal distinctions of these young people.

The Pumé daily discuss individuals they identify only by kin terms, each of which could equally apply to dozens of individuals resident within a camp and hundreds of people in other communities. Geographic residence of the person being described helps clarify whom the kin term refers to. Another way that these references may be distinctive is that speakers use terms appropriate to the ego-centric kin network of the listeners. The convergence of terms in a discussion helps to identify one particular person within the web of networks represented by a particular audience.

Also common in many other kinship systems (Scheffler 1965, 1972), Pumé occasionally use a diminutive form of 'mother' (literally 'little mother') to reference ego's biological mother's sisters (MZ). This is not necessarily an age distinction among women. The 'little mother' term is occasionally extended to co-wives of ego's father, even when they are not ego's MZ. However, the meaning of the term is clearly anchored in its use as a linguistic alternative to identifying all of mother's sisters as 'mother'. No comparable term distinguishes male kin. Although older and younger siblings are used to identify ego's brothers, sisters and parallel cousins, there is no birth-order terminology.

As in many other cultures (Lowie 1920; Marshall 1976; Needham 1954), Pumé women often are referred to within camp using a teknonym, although the term does not literally translate as 'mother of $\mathrm{x}$ (child)'. These teknonyms incorporate the name of a mother's most recent child's Spanish-based name. As with the 'little mother' term applied to MZ, no such teknonymic identification of 'father of $x$ ' is employed for men. These kin conventions make greater distinctions between women than men. This was initially thought to reflect a matrilocal residential focus where potentially larger female family units result in more diverse referent terms. 
This diversity in reference to women is an interesting contrast to the lack of such terms for men. In addition to their potential use in matrilocal residence, such markers used only to distinguish women might be expected in societies with high levels of recognised infidelity and paternal uncertainty. However, among the Savanna Pumé we have not identified any instances of acknowledged or suspected adultery. This is not due to prudery by the Pumé. Topics of social, sexual, or bodily functions are readily discussed by the Pumé and no apparent secret knowledge is held outside of the public sphere. Such linguistic conventions may be a remnant of past social organisation, with comparable levels of infidelity to those found among many tropical South American groups (Gregor 1977; Hill and Hurtado 1996). There are some suggestions that the Pumé are a population that moved into their current territory in the llanos of Venezuela from another region, possibly as refugee former agriculturalists (Leeds 1961; Greaves and Kramer 2014). However, aside from genetic differences (blood group, Layrisse et al. 1961, 1964) and the significant linguistic distinctions from the adjacent Guahiboan populations in the llanos, no secure data can be brought to address this question of past Pumé economics. As noted, we felt that this term diversity might reflect matrilocality. Our observational data and additional census data prior to Greaves's initiation of research in 1990 provide a longitudinal view to address the question of Pumé postmarital residential associations.

\section{Marriage and postmarital residence}

Our goal in this chapter is to address how kinship is used in relationship to cooperation and subsistence in a challenging environment. To understand how the Pumé live in relation to kin networks, we use census data collected over a 25-year period to look at postmarital residence and long-term data on camp membership. This allows us to document whether community associations represent shifting or consistent access to bilateral kin, or are biased towards living with particular kin. We explore how mobility, camp membership and relatedness among Savanna Pumé foragers demonstrate ways that hunter-gatherer populations maximise obligations across broad kinship networks. We contrast the Pumé with other well-known huntergatherer groups to show that there is no single pattern in how foragers associate with and interact with kin. As with many aspects of modern human behaviour and culture, it is the flexibility in recognising the genetic 
relatedness of other individuals that structures cooperative interactions and makes human sociality a highly successful means of surviving in diverse environments.

Among the Pumé, marriage is not formalised through ceremony, but is socially recognised when a man or woman move in together. Divorce likewise is informal and may be instigated by either spouse. Parents and other adult kin have major influences on determining initial marriage partnerships for young people. However, couples autonomously decide whether they remain with their first partners. Subsequent marriages, and first marriages of younger men to older women, are initiated by the couple. Pumé girls marry and initiate reproduction on average at age 15.5 (Kramer 2008). Although many girls are betrothed or cohabit before menarche, coital relations are not initiated before sexual maturity. We have witnessed no examples of coercive sex within the Savanna Pumé, nor heard of any such events from informants. Many young men are married either before sexual maturity or just after puberty. Young couples often initially live in the houses of their parents or other close kin, or in close proximity to them. Postmarital residence with a relative does not have a fixed duration. Following this period, couples may establish their own houses or live in flexible association with younger and older generations. Coresidence of opposite-sex siblings and their spouses within a single household also has been observed. Household kin associations are commonly re-sorted during seasonal camp moves when new structures or house arrangements are made that realign former camp arrangements.

\section{Data collection}

Detailed census and genealogical data collected between 1982 and 2007 are used to examine residential patterns among Pumé foragers. Residence data are extracted from two primary sources: our own census data and Venezuelan indigenous censuses. Greaves conducted censuses and genealogical interviews in 1990, 1992-93 and 2005-07. These interviews were conducted in the Pumé language. The Pumé do not reckon ages but identify life stages associated with specific behaviours (i.e. walking or talking for infants, menarche, marriage, or having had a child), height, or very broad relative age classes (childhood, maturity, and old age). Genealogical data are freely and enthusiastically discussed about both living and dead individuals. Interview methods to determine ages and kin relations are detailed in previous studies (Kramer 2008; Kramer and 
Greaves 2007, 2010; Kramer, Greaves and Ellison 2009). Indigenous censuses of the Pumé were carried out in 1982, 1986, 1988, 1989 and 1992 (Lizarralde and Gragson n.d.). These censuses were collected primarily in Spanish with the assistance of bilingual River Pumé. We use these censuses to extend our residential data and as anchoring events that help determine ages for younger individuals. Both sources of census data are comparable in including names, ages, genealogical data, identification of co-residential units, and past marriage and camp residential histories. The time depth of this detailed sample allows us to examine postmarital residence, shifts in kin associations and stability in residence throughout individual marriages.

Residential data are analysed for two Savanna Pumé villages (Doro Aná and Yagurí) that are part of our current demographic and economic research and for which we have the highest quality data regarding parentage, lateral kinship, and longitudinal data on marriage, reproductive histories, ages, subsistence activities and residence. These two communities are of equivalent size and have a total population of 164 individuals. The sample includes all married adults (105) and all marriages (78) that have occurred or were established since censuses were first collected in 1982. Both villages interact frequently, have close kin ties, and some migration occurs between them as part of postmarital residence. Greaves has worked with both communities since 1990. Both villages were established as part of a migration to this area approximately 45 years ago from the southern portion of Pumé territory near the Cinaruco River.

It is also important to emphasise what we mean by community, village and camps in the context of mobile foragers. The terms community and village refer interchangeably to an association of people that are relatively constant at the scale of the seasonal round. They do not refer to geographic or physical locations. Community or village is the group of people that moves as a population unit during camp residential moves (sensu Binford 1980). Within this broad temporal association, there may be seasonal household reshuffling within a community and the formation of small temporary logistic task groups. Camps identify short-term clusters that may contain various members from the larger community. We return to the issue of hunter-gatherer mobility in the discussion and interpretation of Pumé postmarital residence patterns. 


\section{Data analysis}

Postmarital residence is coded in two ways. First, we identify whether an individual dispersed from his or her natal village at marriage. Individualfocused observation is consistent with how ethologists and primatologists think about dispersal at sexual maturity. Each adult is coded as dispersing or not dispersing from their natal village for their first and all subsequent marriages. Because traditional ethnographic classifications are based on marriage as the unit of analysis, the second way we record postmarital residence is with respect to where a couple resides relative to their kin. Marriages are coded as virilocal, uxorilocal, neolocal or natolocal. We use the term virilocal to identify postmarital residence referent to the husband's kin. Uxorilocal refers to postmarital residence in relation to the wife's kin. A marriage is coded as neolocal if the couple moved to a community separate from close kin of either husband or wife. In a small-scale society this does not mean that they would necessarily move to a community where they have no kin ties. Neolocality identifies couples who disperse away from their natal or closest kin. We use these terms both because they are consistent with how Frank Marlowe (2004) and others (Ember and Ember 1972) coded their cross-cultural samples and because they are a simplification of the complex anthropological vocabulary of postmarital residence in being more inclusive of male and female kin associations. A fourth category, natolocal, is added to refer to endogamous marriages, where both partners remain within their natal community (camp or village) after marriage. Marlowe (2004) notes that natolocality is much more difficult to identify from the Standard CrossCultural Sample for foragers than it is for more sedentary societies. This is partly because the Standard Cross-Cultural Sample presents a static characterisation of societies that cannot systematically address temporal changes in residence and because of the more shifting membership among many foragers. As noted in Figures 7 and 9, we distinguish natolocality referent to foragers' birth village, not just the household in which that individual was born. This modification is necessary among mobile foragers as neither houses, locations, nor intrahousehold membership remains stable across the changes in camp moves. As an example of how to interpret these two coding schemes, if a young woman marries a man from another community and he moves to her community, she is coded as not dispersing, and the marriage is coded as uxorilocal. However, if she married someone within her village, she would be coded as not dispersing and the marriage as natolocal. 
Because the Pumé sample has precise information on where couples live at different points in their adult lives, we track residential stability at two levels. An individual's residential stability is coded both for changes in community affiliation at marriage and for residential moves during a marriage union. The latter records multilocality directly from longitudinal observation. (The terms multilocality and bilocality are used here interchangeably.) Movement within a marriage is recorded for a subset of the population (community of Doro Aná) for whom we have the most continuous observational data.

We clarify that dispersal and postmarital residence are referent to the community in which an individual resided as a juvenile. We refer to this as the natal village because in most cases this is the birth village. To reduce overcategorisation, natolocality includes individuals who have lived in one of the two communities since childhood, but were born elsewhere. In the sample, 18 adults (17 per cent) moved into their 'natal community' as young children. Some of these (33 per cent) moved with their parents during the large migration from the south 45 years ago. Most children, however, joined the study communities because they were orphaned (67 per cent). All computations, descriptive and statistical analyses were preformed in SAS version 9.1.3.

\section{Results}

Postmarital residence was coded for 105 individuals $(55$ women and 50 men) and 78 marriages (Table 1). This included all marriages from two Savanna Pumé villages with a total population of 164 individuals. For all individuals, 32 per cent of men and 22 per cent of women have been married more than once. A nonparametric one-sided WilcoxonMann-Whitney test shows that while males tend to remarry more often, this difference is not significant $(z=1.2006, p=.1149, n=105)$. Although many young adults have been married more than once, age is obviously a significant determinant of times married (model $f=5.58, d f$ $=3, p=.0007, n=105$ for a multivariate general linear model [GLM] including age $[p=.0002]$ and a quadratic term for age $[p=.0002])$. Older individuals are more likely to experience multiple marriages, but sex is not significant when added to the model $(p=.2741)$. Men (15.5 per cent) more commonly than women ( 6.5 per cent) have been polygynously married at some point in their adult lives. Of the 78 marriages, 62 are first marriages, 14 are second marriages and two are third or more marriages. 
Table 1. Pumé sample description

\begin{tabular}{|c|c|c|}
\hline Married individuals $(n=105)$ & Males & Females \\
\hline & 50 & 55 \\
\hline $\begin{array}{c}\text { Times married } \\
1 \\
2 \\
3+\end{array}$ & $\begin{array}{c}34 \\
14 \\
2\end{array}$ & $\begin{array}{c}43 \\
11 \\
1\end{array}$ \\
\hline Polygynously married & $15.5 \%$ & $6.5 \%$ \\
\hline \multicolumn{3}{|l|}{ Marriages $(n=78)$} \\
\hline $1^{\text {st }}$ marriage & \multicolumn{2}{|c|}{$\begin{array}{c}62 \\
(79.5 \%)\end{array}$} \\
\hline $2^{\text {nd }}$ marriage & \multicolumn{2}{|c|}{$\begin{array}{c}14 \\
(17.9 \%)\end{array}$} \\
\hline $3^{r d}+$ marriage & \multicolumn{2}{|c|}{$\begin{array}{c}2 \\
(2.6 \%)\end{array}$} \\
\hline
\end{tabular}

Source: Constructed by (C) Russell D. Greaves and Karen L. Kramer from their fieldwork data and the Lizarralde and Gragson n.d. census data-RG.

Figure 7 shows individual dispersal patterns for Pumé males $(n=49)$ and females $(n=54)$. The precise dispersal history of two older adults was unclear despite multiple interviews. The majority of men (86 per cent) and women (76 per cent) marry endogamously and remain in their natal village, at least for the entire duration of their first marriage. While more females disperse than males, this difference is not significant $($ Chi-sq $=$ $1.5730, d f=1, p=.2098)$.

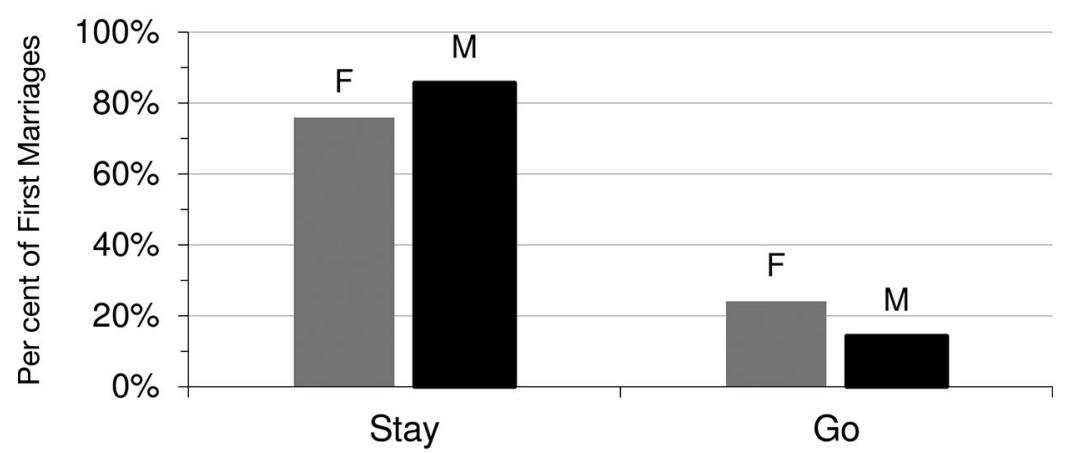

Figure 7. Pumé postmarital dispersal patterns from natal village for first marriage

( $n=49$ males, black bars; $n=54$ females, grey bars)

Source: Constructed by (C) Russell D. Greaves and Karen L. Kramer from their fieldwork data and the Lizarralde and Gragson n.d. census data-RG. 
To situate postmarital residence patterns as they are commonly coded in ethnographic studies, marriage as the unit of analysis is stratified by postmarital residence. Of first marriages $(n=62), 66$ per cent are natolocal (Figure 8). Virilocality, where wives emigrate to their husbands' community, occurs in 19 per cent of marriages. Uxorilocality, where husbands move to their wives' communities, occurs in 15 per cent of marriages.

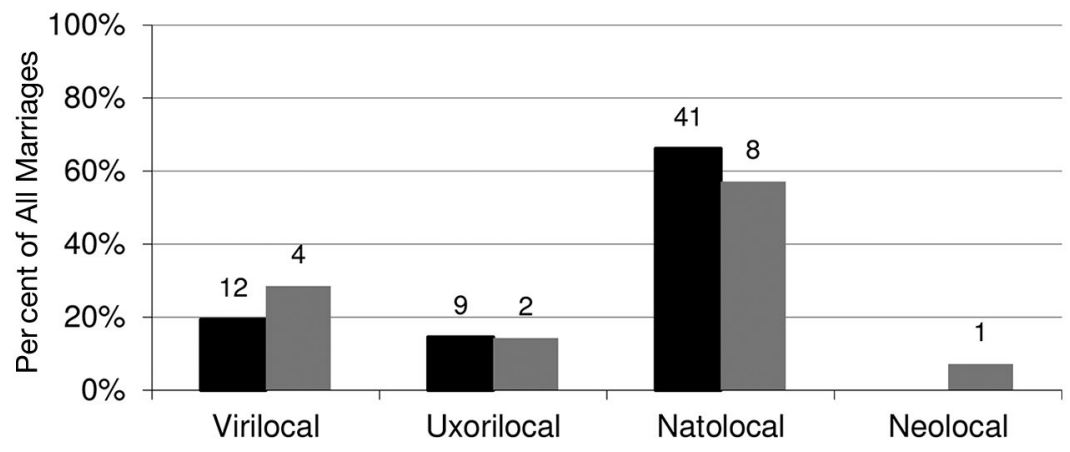

Figure 8. Pumé postmarital residence patterns

Marriages stratified by whether the couple resides with the husband's relatives (virilocal), the wife's relatives (uxorilocal), in their natal village (natolocal), or in a village where neither has close relatives (neolocal). Shown for first marriages (black bars; $n=62$ ), and second marriages (grey bars; $n=15$ ).

Source: Constructed by $\odot$ Russell D. Greaves and Karen L. Kramer from their fieldwork data and the Lizarralde and Gragson n.d. census data-RG.

Residence decisions during second marriages are examined separately for several reasons. To maximise sample size, individuals of different ages and couples at different stages in their reproductive careers are included. First marriages are overrepresented since all couples have at least one marriage to be included in the sample, but not all couples have completed their marital history. First and second marriages may show different residential choices, with distinctions between younger and older individuals based on number of children, extent of within-community alliances, or mate availability. Despite these potential differences of residence selection following divorce or at initiation of a subsequent union, the pattern for second marriages is remarkably similar to that of first marriages (Figure 9). Although a slightly higher proportion of individuals emigrate following a second marriage, this difference is not significant (Chi-sq $=.6043, d f=$ $2, p=.7392)$. The majority of second marriages are natolocal, with both 
partners continuing to remain associated with their natal community and that of their first marriages. Only one case of neolocality was identified in our sample.

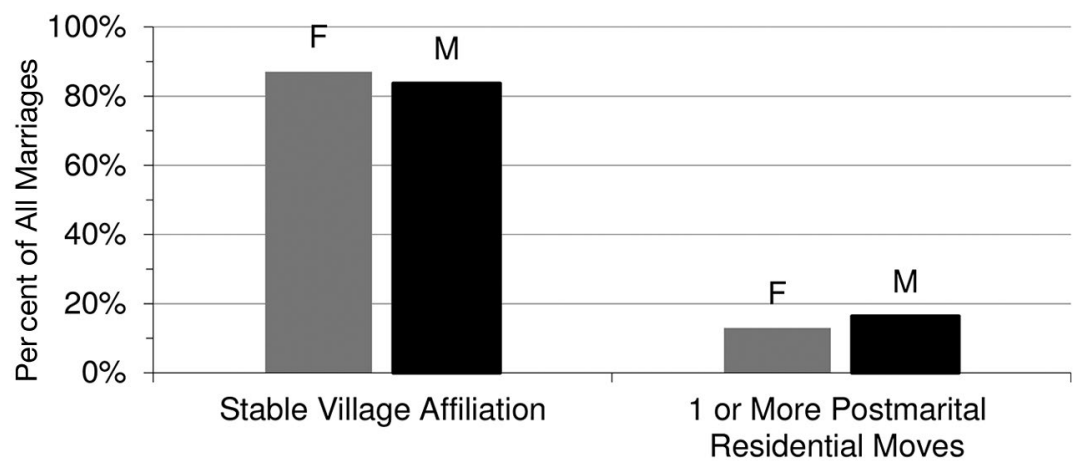

Figure 9. Postmarital residential stability for Pumé residents ( $n=49$ males, black bars; $n=54$ females, grey bars)

Source: Constructed by (C) Russell D. Greaves and Karen L. Kramer from their fieldwork data and the Lizarralde and Gragson n.d. census data-RG.

Postmarital residential stability evaluates the extent to which Pumé men and women shift their kin associations with subsequent marriages. Figure 7 shows the frequency distribution for males and females who remain in the community where they first reside after marriage (whether it is natolocal, virilocal, or uxorilocal) compared to those who make one or more additional residential moves during subsequent marriages. All first marriages within both communities are shown in Figure 9. Most Pumé women (87 per cent; $n=54$ ) and men (84 per cent; $n=49$ ) remain affiliated with the same community where they lived at the time of their first marriage. Postmarital residential stability is independent of sex (Chi-sq = .2336, $d f=1, p=.6289$ ). When the probability that someone who dispersed at first marriage will continue to move during subsequent marriages is modelled, results are insignificant (Wald chi-sq $=.9781$, $p=.3227, n=103)$. While exogamous dispersal at first marriage is not a significant predictor of subsequent community shifts for later marriages, it is notable that the several individuals who have been married three or more times have made multiple residential moves during their adult lives.

Residential changes within a marriage also are rare. Ninety-one per cent ( $n=42$ marriages) of couples remain associated with the same community throughout their marriage. Couples that do move tend to be young and 
the wife and husband each have at least one living parent (so that such a move is not neolocal). These couples move infrequently between their parents' communities. While the Pumé have a strong bilateral residence pattern, there is a low incidence of multilocality.

In sum, although the Pumé have been culturally characterised as a matrilocal foraging society, longitudinal census data and residential analyses provide a different and more nuanced view of postmarital decisions. There is no evidence of predominantly sex-biased dispersal. Neither men nor women preferentially relocate from their village residence following marriage. Most marriages in our sample are natolocal, both spouses remaining in the community where they grew up throughout their adult lives. Individuals that do move after their first marriage exhibit minimal subsequent residential reshuffling. Although the incidence of bilocality at the scale of community relocation is low, we emphasise in the discussion that natolocality is functionally a similar strategy that maintains bilateral kin affiliations.

\section{Discussion}

The perception that hunter-gatherers are patrilocal persists in many formulations about human social organisation despite numerous ethnographic examples to the contrary. Recent cross-cultural comparisons demonstrate that the predominant residential pattern among modern foragers is neither male- nor female-focused, but bilateral, in which ties to both male and female kin are maintained (Figure 10). Foragers also trace descent bilaterally more frequently than do nonforagers (Marlowe 2004). Together these patterns strongly suggest that an important general characteristic of hunter-gatherer social organisation is access to a broad pool of kin through flexible residential association and recognition of more kinds of kin than seen among nonforaging groups. Even in societies that may be characterised as patrilocal or matrilocal, the recognition that they still calculate bilateral kin has become a mundane anthropological assumption. However, recognition of bilateral kin is a unique behaviour even among the most social of other animals (Alexander 1979; Alexander and Noonan 1979; Rodseth et al. 1991). The Pumé results complement cross-cultural studies in using individual-level, longitudinal behavioural data to show that postmarital residence is organised to maintain strong bilateral kin ties. 


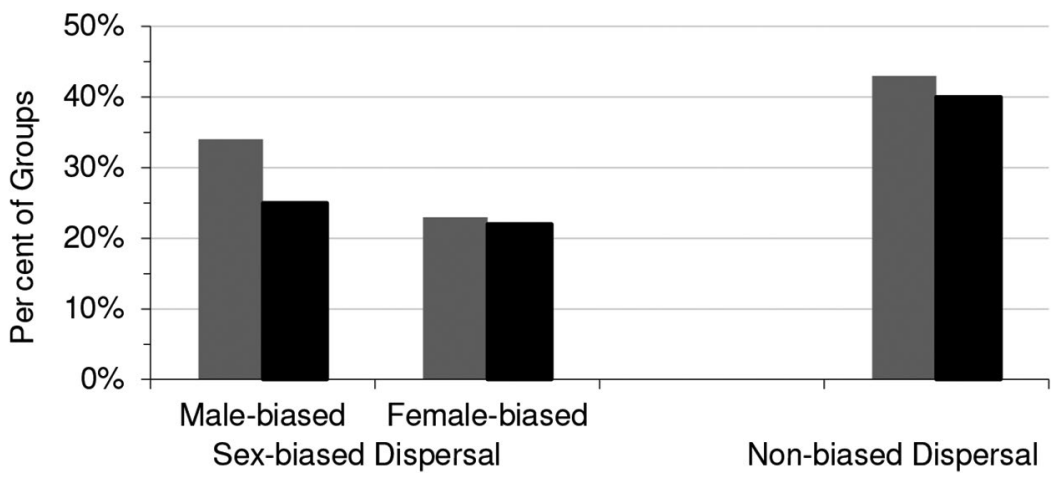

Figure 10. Reassessment of hunter-gatherer postmarital patterns from Marlowe (2004: 280)

Source: Constructed by (c) Russell D. Greaves and Karen L. Kramer from Marlowe (2004: 280), $n=36$ groups from the Standard Cross-Cultural Sample, grey bars (Alvarez 2004); $n=48$ groups from Murdock's 1967 Ethnographic Atlas, black bars.

Results show a clear pattern of natolocality among the Savanna Pumé that keeps both spouses across most marriages in close association with their immediate and extended families. Although cross-cultural analyses show that the proportions of male contributions to the overall forager diet do not result in higher levels of virilocality (Marlowe 2004), there are suggestions that uxorilocality may be associated with higher amounts of women's contributions (Korotayev 2001; Marlowe 2004; Scelza and Bliege Bird 2008). Given the characterisation of the Pumé as matrilocal and the relative equality in importance of male and female foods to their diet, we expected that there might be some biases in the variation toward that pattern. Although there is much reliance on female food contributions, residence favouring association with more female kin is not apparent.

We expected that there might be differences in postmarital residence between first and subsequent marriages. Residential decisions may be made for various reasons, and second marriages may be made for different reasons than initial unions. Younger individuals may be less tethered to one community because they have fewer child-support demands and lessdeveloped adult relationships. Older individuals may be more interested in remaining in the village they first marry into because of children, offspring support from former spouses or other kin, extant friendships, labour or sharing alliances that are costly to abandon. Divorce could engender potential conflicts resulting in more exogamous second marriages compared with first unions. However, these life-history changes 
appear to have little effect on residence location following remarriage. For all marriages, natolocal and exogamous, lifetime association most commonly remains with the community of initial postmarital residence. This suggests that established adult relationships, which involve frequent labour and sharing interactions, are important considerations in decisions about where to live following divorce. Although there is lability in group composition during temporary camps, visits or seasonal household reorganisation, primary village associations are remarkably stable.

While natolocality and postmarital residential stability are strong patterns, some Pumé do separate from their kin and emigrate to households within their husbands' or wives' communities (20 individuals' first marriage, 19.4 per cent of males and females in the sample). Three of these are older individuals who emigrated from the parent population that formed the communities of Doro Aná and Yagurí 45 years ago. Two individuals represent the one neolocal marriage in our sample. One woman and her younger brother moved in as young orphans and both married within this adoptive group. While multivariate analyses might bring greater insight into the conditions under which individuals deviate from the natolocal pattern, the sample of exceptions is too small. However, in examining these exogamous marriages, we found a suggestive patterned difference between men and women that provides a direction for future research.

Of the remaining 13 men and women whose first marriages were nonnatolocal (four men and nine women), the majority of the exceptions fall into two general categories. Most males who relocate into uxorilocal postmarital residence are part of large families. They appear to emigrate because their available mating options are already coopted by older siblings and male parallel cousins. All four men who married exogamously had at least three living siblings in their natal communities. In contrast, women who emigrate into the communities of their husbands tend to have few close kin of their own, and gain larger kin networks through alliances with their husbands' families. Two of the women had no living siblings and small families. Another young woman married exogamously when she had only one full sibling in her natal group, her mother had recently remarried and the family's status was relatively low. Three women who initially resided virilocally during their first marriages have subsequently divorced and returned to their natal communities. One woman had been raised for most of her life in the non-natal community where she married, her father still lives there and her mother lived there for approximately 13 years. One woman followed her husband's relocation to a village 
where his brother lived, although they both initially resided in her birth community. The remaining woman's situation does not appear to fit our generalisation about exogamous marriage. There is no indication that sororal polygyny is associated with exogamous female marriage among the Savanna Pumé, as found among other foragers (Scelza and Bliege Bird 2008). Additional support of these patterns is apparent in exogamous third and fourth marriages. ${ }^{1}$ In mobile hunter-gatherers the complexities of residential shifts across the life span reinforce the importance of bilateral kin association. For example, the three women who returned to their natal communities subsequent to dissolution of an exogamous postmarital residence and the one woman who had lived as a child in the nonnatal community where she married (also see two similar exceptions in footnote 1) demonstrate a preponderance of bilateral kin proximity.

In small populations, low levels of exogamous marriage persisting over a long period raise obvious concerns about incest avoidance (Bittles 2004; Durham 2004). One observation from our fieldwork may address this concern and provide insight into a less appreciated form of mobility in small-scale societies. Although Pumé community associations are relatively stable both at marriage and throughout the duration of a marriage, major reshuffling of kin affiliations does occur at a deeper temporal scale.

Both study communities moved to their current territory approximately 45 years ago from further south near the Cinaruco River. The adults in the generation who moved state that they represent more distantly related individuals from less intermarried lineage segments who fissioned from their parent community. Additionally, following this fission, some individuals from nearby villages joined these new communities. This move occurred before the data collection used in these analyses, and

\footnotetext{
1 The importance we infer for bilateral kin access is also supported by the 12 examples of non-natolocal second-fourth marriages in our sample. Four (three men, one woman) of the eight individuals with two non-natolocal marriages initiated their first union natolocally, and subsequently sought mates in other communities. Two of those same men, and another woman with exogamous second marriages had lived in the community they married into as pre-adolescent children for at least 10 years before moving away with their parents. One other man's second marriage took place uxorilocally within the same community that he had married into 13 years previously. One woman's second and third marriages were both exogamous (as was her first), although she had lived extensively in the two communities where her second-third marriages occurred. She also had a small number of relatives in both groups. Only one woman exhibited both marriages that were virilocal without having local kin. The other non-natolocal third $(n=2)$ and fourth $(n=1)$ unions (representing two men) were by individuals whose first marriages were natolocal. Both of these men with the highest number of exogamous marriages come from a family with a large number of surviving full and halfbrothers (and natolocally resident sisters).
} 
confirmation of the relatedness of individuals in this founder group compared to their original community membership is beyond the reach of the current genealogical data. Following the consequences of the Darkness in El Dorado scandal (Borofsky 2005; Gregor and Gross 2004; Tierney 2000), genetic testing is unlikely to be permitted by government ministries in Venezuela to resolve this issue. Informants, however, are clear in their statements that they moved to their current location as less-related families from their source residence. This recent migration offers new marriage options through a temporal and geographic reassortment of the population. These two communities retain ties with each other and with other families who also dispersed into other Pumé villages. These provide an additional destination and source for low-frequency exogamous marriages. For example, as noted above in the discussion of exogamous marriages, some camp moves do bring in new members whose children marry natolocally (by our coding criteria) but represent individuals from outside family groups. While it is unknown whether such reshuffling is a consistent feature of Pumé demography or explains natolocality in other contexts, such large-scale population shifts are known for other foragers (Blackburn 1996; Denbow 1984; Wilmsen 1989).

Another question raised by these analyses, is the role of affinal kin in comparison to the apparent importance of bilateral kin access. Both male and female resources are widely shared within Savanna Pumé communities (Gragson 1989; Greaves and Kramer 2014; Kramer and Greaves 2010; Mitrani 1988), and there is no evidence of strict in-law avoidance or preferential association in relation to subsistence work or food sharing (Mitrani 1988). Quantitative time allocation data would further clarify whether the strength of interactions varies between affines and consangual kin. Time allocation data on sharing and other interactions, the spatial proximity of wives' and husbands' parents or other in-laws (data available from one Pumé community), and longitudinal persistence (potentially available for some of the 25 -year genealogical sample) could contribute to an improved understanding of affinal roles and variation by sex and generation (Coall and Hertwig 2010; Euler and Weitzel 1996; Euler and Michalski 2007). 


\section{Environmental influences on bilateral kinship organisation}

The observation that hunter-gatherers exhibit greater bilateral kin identification and more bilaterally referenced residence than nonforaging societies (Marlowe 2004) suggests that reliance on wild foods is related to broad kinship networks (Ember 1975; Lee 1972, 1979; Silberbauer 1972). Many foragers exploit a wide diversity of food resources with distinct and variable distributions, return payoffs, access and processing requirements. Resource variation must be mediated through an array of mobility, labour and group size changes (Binford 2001; Kelly 1995; Panter-Brick, Layton and Rowley-Conwy 2001; Quinlan and Quinlan 2007; Scelza and Bliege Bird 2008; Smith 1991; Winterhalder and Smith 1981). Seasonality influences all of these changing needs, including the sex of primary producers and their labour (i.e. multiple female or male membership groups) and support (i.e. childcare, food processing, mobility, auxiliary help roles) demands. Kinship association is an important means to assemble and alter social memberships, at potentially different geographical and temporal scales, in response to these changes. Foragers living in small communities necessarily cope with variation in sex ratios, age profiles, productivity and generosity of kin, as well as both anticipated and unforeseen changes in environmental conditions affecting subsistence, stress, and future options. In addition, hunter-gatherers may use mobility or kinship to change relationships between producers and consumers, to recruit labour groups appropriate for particular tasks or to adjust for food availability during certain times of the year.

If foragers tend to be more inclusive of bilateral kin relationships than nonforagers, is this evident in the different kinds of camps they make? We use the Savanna Pumé results to address how bilateral kin affiliation can be broadly similar across hunter-gatherers despite differences in mobility, camp size and residence patterns. We contrast pumé natolocality with the multilocal residence and uxorilocal bias of the Hadza of Tanzania to demonstrate how both of these apparently distinct and different living arrangements each accomplish similar maximisation of lifetime association with a broad set of bilateral kin.

Membership at Pumé main residence camps is stable across all seasonal moves. Except for short-term camps, almost identical groups are present in each co-resident association across our 25 -year sample. The predominant pattern of Pumé natolocality appears to be a response, in part, to their 
marginal environment. Six months of each year are associated with seasonal shortfalls in food availability, nutritional stress and increased epidemiological challenges. During this season, few men hunt on any particular day and returns are normally much smaller than among many foragers (Greaves 1997b). Low wet-season inputs of protein and fat are offset by highly predictable and larger returns by women collecting tubers (Greaves and Kramer 2014; Kramer and Greaves 2017). Unlike many other foragers, female foods are extensively shared. These factors may condition living with as broadly inclusive a male and female kin base as possible. Smaller camps might have fewer consumers, but they also would have fewer hunters, smaller areas searched by hunters and lower male food returns. In a relatively depauperate terrestrial environment, wet-season camps may not atomise because a certain threshold number of men are necessary to realise any hunting success. Because husbands and wives are always co-resident, this results in a matched labour force. The stability of natolocality appears to be an outcome of living in aggregate groups of bilateral kin, which may be favoured to minimise resource shortfalls. It is notable that smaller temporary camps are common only during the dry season, when food is more widely available and parts of the community move to productive fishing locations for one to three weeks.

\section{Comparisons to other hunter-gatherers}

In contrast, the Hadza rotate membership across a range of smaller shortterm camps (Marlowe 2006, 2010; Woodburn 1968, 1972). Unlike the Venezuelan savanna, the Hadza environment has a greater availability of large game, tubers of larger package size and reliable sources of densely caloric honey. Individual camps are generally smaller $(-20-60$ individuals) than most Savanna Pumé residential camps, and potential kin associations at any particular camp are less diverse. Hadza men and women move between several small camps on average 6.5 times a year ranging between 4-20 camp moves per year (Marlowe 2010). The Hadza calculate bilateral kinship and have generally uxorilocally referenced camp residence (Woodburn 1972). The differences between Hadza and Pumé camps on the ground reflect distinct ways of employing bilateral kin (Figure 11), which are linked to differences in camp size, aggregation and the higher productivity of the Hadza environment. Only a minority of Hadza camp moves appear to be related to food shortages, partly because small numbers of producers can have an assurance of returns and smaller camp size reduces the numbers of consumers (Woodburn 1972). 
Although each individual Hadza camp may be composed of a narrower range of kin, individuals or couples, they associate with a broad range of bilateral kin throughout their lives. At a deeper temporal scale, each of these temporary camps combines into a larger bilateral kin network (Wood and Marlowe 2011).

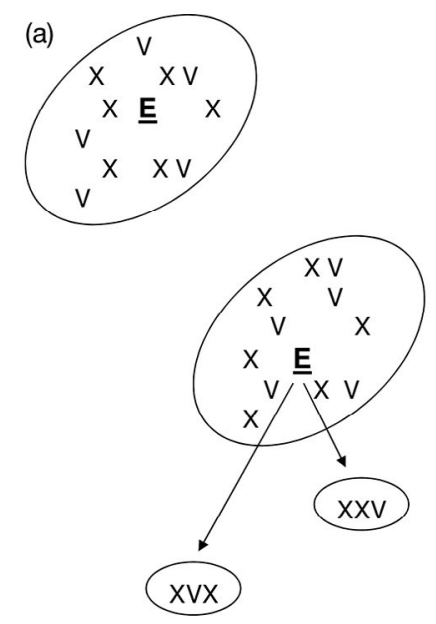

(b)

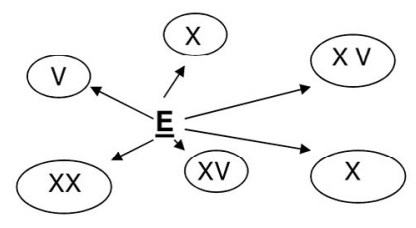

Figure 11. Schematic model of a married hunter-gatherer's relationship to bilateral kin under two common residential patterns

(a) natolocal residence and stable camp composition, showing occasional temporary camps (Pumé-type pattern); (b) multilocal residence and a shifting camp composition (Hadzatype pattern). Each model represents ego's $(E)$ residential mobility and the hypothetical assortment of kin ( $\mathrm{X}=$ uxorilocal, $\mathrm{V}=$ virilocal) within individual camps across an unspecified time period.

Source: Drawn by @ Russell D. Greaves and Karen L. Kramer.

The schematic differences between two residential systems such as those practised by the Pumé or the Hadza are shown in Figure 11. The figure outlines kin associations in a natolocal and a multilocal residential system as they might appear across time. The view shows ego's (E) relationships to uxorilocal (X) and virilocal (V) kin who are resident in each camp. Because a hunter-gatherer's individual residential events are subsumed within a larger pattern of lifetime interactions, this is a useful scale to examine the cumulative system effects of forager residential organisation. Figure 11 illustrates how both natolocal and multilocal residence affect a similarly broad set of bilateral kin associations.

The residential variation seen among Ju/hoansi foragers, who live in comparable savanna settings, also emphasises the importance of maintaining access to bilateral kin. Researchers working with Ju/'hoansi 
recognise the importance of variable residence associations across a broad suite of potential bilateral kin that are responsive to environmental, social, and life history changes in foraging opportunities. Richard B. Lee (1976, 1979) contradicts Lorna Marshall's (1960) position on patrilineal control over waterholes and associated resource areas. Lee explicitly underlines the flexible associations among kin across !Kung camp moves (1979: 61-67, tables 3.13-3.14, figures 3.4-3.6). Marshall (1976) describes highly variable potential kin associations, even with an expected period of residence with uxorilocal kin for bride service. Lee (1979) agrees with this point and indicates that even bride service may include the relocation of a husband's kin to create a bilateral kin-based residential camp rather than a strictly uxorilocal-referenced postmarital residence. Looking at women's residence choices among the !Kung, Howell (2001) states that post-divorce residence may be determined by the amount of time in a particular community before divorce, whether the woman has kin in that group, if her parents are still living, whether her children were married or the possibility of remarriage to a brother of her ex-husband. Polly Wiessner (2002) also emphasises the egalitarian options of men and women in choosing associations with particular kin. She identifies group membership as facultative and at least partially related to hunting ability of central males. Wiessner (ibid.: 422-27, tables 2-4) calculates that productive males also have significantly more sharing partners among distant kin than poorer hunters, indicating opportunities to extend their networks well beyond those of less-skilled hunters who primarily have support relationships only with more closely related individuals.

Like the Hadza example outlined above, temporal changes in camp membership result in multiple patterns of residential association with bilateral kin, not an adherence to any strict and biased norm of preferential residence with a more limited set of relatives. For Ju'hoansi, food shortages are not uncommon and a similar shifting residential pattern to that employed by the Hadza in a more resource-rich environment is used as a social means of accessing variable returns from men and women who are both close and more distant kin. The variability in Ju'/hoansi seasonal subsistence activities, fluctuating annual and interannual rainfall, and occasionally extreme differences in resource availability, appears to result in a flexible residential system that maximises potential access to diverse locations through fluid tactical associations with a range of kin. 


\section{Conclusions}

Our goal in this chapter is to further investigate the challenge from recent cross-cultural comparisons that bilateral rather than sex-biased kin affiliations are an important pattern in human postmarital residence using longitudinal and individual observations for a group of mobile foragers. The Savanna Pumé combine close and more distant biological kin, along with affines, into networks that generally persist for life. Long-term shifts in population reorganise mobile Pumé communities so that natolocality is a stable strategy maintaining broad bilateral kin associations. Cross-cultural studies have shown that bilateral kin associations are more common in forager than food-producing populations. Additionally, such broad access to kin is associated with a range of environments, resource productivity, and huntergatherer subsistence practices. We emphasise that natolocality, bilocality and multilocality accomplish similar ends in maximising bilateral kin affiliations compared to sex-biased kin affiliations. Distinctions between huntergatherer residential organisations appear to be responses to environmental differences that adjust labour groups and camp size through manipulation of kin associations. Such flexible changes in forager group composition are possible because humans recognise a broad range of relatives.

Descent and genetic relatedness are the bases for these kinship systems that secondarily link affines into an extensive network. The additional layering of more facultative kinship extends the categories and obligations based on descent to individuals of economic value and interest (such as good producers or visiting anthropologists) to the cooperating community. Far from being a cultural construct of human ideation, human kinship is grounded in biology. Our unique human diversity employs myriad languages, forms of social organisation, knowledge systems, and subsistence adaptations across the world. However, a relatively limited number of ways to describe kin associations between individuals are flexibly used as critical components in those different behavioural strategies for social cooperation. In contrast, the more limited variety in kinship classification systems used globally reflects their biological basis in descent. However, how kinspeople distribute themselves in residential and subsistence groups is responsive to the broad range of environmental and social challenges that humans face. 


\section{References}

Alexander, Richard D. 1979. Darwinism and Human Affairs. Seattle: University of Washington Press.

Alexander, Richard D. and Katherine M. Noonan. 1979. 'Concealment of ovulation, parental care, and human social evolution'. In Evolutionary Biology and Human Social Behavior: An Anthropological Perspective, edited by Napoleon A. Chagnon and William Irons, 402-35. North Scituate: Duxbury Press.

Allen, Nicholas J., Hilary Callan, Robin Dunbar and Wendy James (eds). 2008. Early Human Kinship: From Sex to Social Reproduction. Malden: Blackwell Publishing. doi.org/10.1002/9781444302714

Alvard, Michael S. 2002. 'Carcass ownership and meat distribution by big-game cooperative hunters'. Research in Economic Anthropology 21: 99-132. doi.org/10.1016/S0190-1281(02)21005-7

- 2003. 'Kinship, lineage identity, and an evolutionary perspective on the structure of cooperative big game hunting groups in Indonesia'. Human Nature 14(2): 129-63. doi.org/10.1007/s12110-003-1001-5

Alvard, Michael S. and David A. Nolin. 2002. 'Rousseau's whale hunt? Coordination among big game hunters'. Current Anthropology 43(4): 533-59. doi.org/10.1086/341653

Alvarez, Helen Perich. 2004. 'Residence groups among hunter-gathers: A view of the claims and evidence for patrilocal bands'. In Kinship and Behavior in Primates, edited by Bernard Chapais and Carol M. Berman, 420-42. Oxford: Oxford University Press.

Barry, Herbert and Alice Schlegel (eds). 1980. Cross-Cultural Sample and Codes. Pittsburgh: University of Pittsburgh Press.

Berndt R.M. and C.H. Berndt (eds). 1965. Aboriginal Man in Australia. Sydney: Angus and Robertson.

Bicchieri, M.G. (ed.). 1972. Hunters and Gatherers Today: A Socioeconomic Study of Eleven Such Cultures in the Twentieth Century. New York: Holt, Rinehart and Winston. 
Binford, Lewis R. 1980. 'Willow smoke and dogs' tails: Hunter-gatherer settlement systems and archaeological site formation'. American Antiquity 45(1): 4-20. doi.org/10.2307/279653

—_. 2001. Constructing Frames of Reference: An Analytical Method for Archaeological Theory Building Using Ethnographic and Environmental Data Sets. Berkeley: University of California Press.

Bittles, Alan H. 2004. 'Genetic aspects of inbreeding and incest'. In Inbreeding, Incest, and the Incest Taboo: The State of Knowledge at the Turn of the Century, edited by Arthur P. Wolf and William H. Durham, 38-60. Stanford: Stanford University Press.

Blackburn, Roderic. 1996. 'Fission, fusion, and foragers in East Africa: Micro- and macroprocesses of diversity and integration among Okeik'. In Cultural Diversity Among Twentieth Century Foragers: An African Perspective, edited by Susan Kent, 188-212. Cambridge: Cambridge University Press.

Blurton Jones, Nick, Kristen Hawkes and James F. O’Connell. 2005. 'Older Hadza men and women as helpers'. In Hunter-Gatherer Childhoods: Evolutionary, Developmental and Cultural Perspectives, edited by Barry S. Hewlett and Michael E. Lamb, 214-36. New Brunswick: Aldine Transactions.

Bogin, Barry. 1999. Patterns of Human Growth. 2nd edition. Cambridge: Cambridge University Press.

Borofsky, Rob. 2005. Yanomami: The Fierce Controversy and What We can Learn from It. Berkeley: University of California Press.

Brown, Melissa J. (ed.). 2008. Explaining Culture Scientifically. Seattle: University of Washington Press.

Cant, Michael A. and Rufus A. Johnstone. 2008. 'Reproductive conflict and the separation of reproductive generations in humans'. Proceedings of the National Academy of Sciences 105(14): 5332-36. doi.org/10.1073/pnas.0711911105

Carroll, Vern (ed.). 1970. Adoption in Eastern Oceania. Honolulu: University of Hawaii Press. 
Cavalli-Sforza, Luigi Luca. 1997. 'Genes, people, languages'. Proceedings of the National Academy of Sciences 94(15): 7719-24. doi.org/10.1073/ pnas.94.15.7719

Chagnon, Napoleon A. and William Irons (eds). 1979. Evolutionary Biology and Human Social Behavior: An Anthropological Perspective. North Scituate: Duxbury Press.

Chapais, Bernard and Carol M. Berman (eds). 2004. Kinship and Behavior in Primates. Oxford: Oxford University Press.

Coall, David and Ralph Hertwig. 2010. 'Grandparental investment: Past, present and future'. Behavioral and Brain Sciences 33(1): 1-59. doi.org/10.1017/S0140525X09991105

Costopoulos, Andre. 2005. 'On comparative studies using Standard CrossCultural Sample data: Monte Carlo simulation of artificial trends'. Current Anthropology 46(3): 457-59. doi.org/10.1086/430014

de Carrocera, Buenaventura, O.F.M. (1980). 'Lingüística indígena venezolana y los misioneros Capuchinos'. Montalban 10: 203-530.

Denbow, J.R. 1984. 'Prehistoric herders and foragers of the Kalahari: The evidence for 1500 years of interaction'. In Past and Present in Hunter-Gatherer Studies, edited by Carmel Shrire, 175-93. New York: Academic Press.

Destro-Bisol, G., F. Donati, V. Coia, I. Boschi, F. Verginelli, A. Caglià, S. Tofanelli, G. Spedini and C. Capelli. 2004a. 'The analysis of variation of mtDNA hypervariable region I suggests that eastern and western Pygmies diverged before the Bantu expansion'. American Naturalist 163(2): 212-26. doi.org/10.1086/381405

—. 2004b. 'Variation in female and male lineages in Sub-Saharan populations: The importance of sociocultural factors'. Molecular Biology and Evolution 21(9): 1673-82. doi.org/10.1093/molbev/msh186

Di Fiore, Anthony and Drew Rendall. 1994. 'Evolution of social organization: A reappraisal for primates by using phylogenetic methods'. Proceeding of the National Academy of Sciences 91: 9941-45. doi.org/10.1073/pnas.91.21.9941 
Divale, William Tulio. 1974. 'Migration, external warfare, and matrilocal residence'. Behavior Science Research 9(2): 75-133. doi.org/ $10.1177 / 106939717400900201$

Donald, Leland. 1997. Aboriginal Slavery on the Northwest Coast of North America. Berkeley: University of California Press. doi.org/10.1525/ california/9780520206168.001.0001

Dunbar, Robin. 2008. 'Kinship in biological perspective'. In Early Human Kinship: From Sex to Social Reproduction, edited by Nicholas J. Allen, Hilary Callan, Robin Dunbar and Wendy James, 131-50. Malden: Blackwell Publishing. doi.org/10.1002/9781444302714.ch7

Durham, William H. 2004. 'Assessing the gaps in Westermarck's theory'. In Inbreeding, Incest, and the Incest Taboo: The State of Knowledge at the Turn of the Century, edited by Arthur P. Wolf and William H. Durham, 121-38. Stanford: Stanford University Press.

Ember, Carol R. 1975. 'Residential variation in hunter-gatherers'. Cross Cultural Research 10(3): 199-227. doi.org/10.1177/106939 717501000302

—_. 1978. 'Myths about hunter-gatherers'. Ethnology 17(4): 439-48. doi.org/10.2307/3773193

Ember, Carol R. and Melvin Ember. 1972. 'The conditions favoring multilocal residence'. Southwestern Journal of Anthropology 28(4): 382-400. doi.org/10.1086/soutjanth.28.4.3629318

Ember, Melvin and Carol R. Ember. 1971. 'The conditions favoring matrilocal versus patrilocal residence'. American Anthropologist 73(3): 571-94. doi.org/10.1525/aa.1971.73.3.02a00040

Euler, Harald A. and Richard L. Michalski. 2007. 'Grandparental and extended kin relations'. In Family Relationships: An Evolutionary Perspective, edited by Catherine A. Salmon and Todd K. Shackelford, 230-55. New York: Oxford University Press. doi.org/10.1093/ acprof:oso/9780195320510.003.0011

Euler, Harald A. and Barbara Weitzel. 1996. 'Discriminative grandparental solicitude as reproductive strategy'. Human Nature 7(1): 39-59. doi.org/10.1007/BF02733489 
Gragson, Ted L. 1989. 'Allocation of time to subsistence and settlement in a ciri khonome Pumé village of the Llanos of Apure, Venezuela'. PhD thesis, Pennsylvania State University, Pittsburgh.

Gray, J. Patrick and Andre Costopoulos. 2006. 'On artificial trends in comparative studies using Standard Cross-Cultural Sample data'. Current Anthropology 47(1): 149-51. doi.org/10.1086/498954

Greaves, Russell D. 1997a. 'Ethnoarchaeological investigation of subsistence mobility, resource targeting, and technological organization among Pumé foragers of Venezuela'. PhD thesis, University of New Mexico, Albuquerque.

- 1997b. 'Hunting and multifunctional use of bows and arrows: Ethnoarchaeology of technological organization among Pumé hunters of Venezuela'. In Projectile Technology, edited by Heidi Knecht, 287320. Interdisciplinary Contributions to Archaeology Series. New York: Plenum Press. doi.org/10.1007/978-1-4899-1851-2_12

- 2006. 'Forager landscape use and residential organization'. In Archaeology and Ethnoarchaeology of Mobility, edited by Frederic Sellet, Russell D. Greaves and Pei-Lin Yu, 127-52. Gainesville: University Press of Florida.

Greaves, Russell D. and Karen L. Kramer. 2014. 'Hunter-gatherer use of wild plants and domesticates: Archaeological implications for mixed economies before agricultural intensification'. Journal of Archaeological Science 41: 263-71. doi.org/10.1016/j.jas.2013.08.014

Gregor, Thomas. 1977. Mehinaku: The Drama of Daily Life in a Brazilian Village. Chicago: University of Chicago Press.

Gregor, Thomas A. and Daniel R. Gross. 2004. 'Guilt by association: The culture of accusation and the American Anthropological Association's investigation of Darkness in El Dorado'. American Anthropologist 106(4): 687-98. doi.org/10.1525/aa.2004.106.4.687

Helm, June. 1965. 'Bilaterality in socio-territorial organization of the Arctic Drainage Dene'. Ethnology 4(4): 361-85. doi.org/10.2307/ 3772786

Hervás y Panduro, Lorenzo. 1979. Catálogo de las Lenguas de las Naciones Conocidas: y Numeración, División y Clases de Estas Según la Diversidad de sus Idiomas y Dialectos, vol. 1. Madrid: Ediciones Atlas. 
Hewlett, Barry S. and Michael E. Lamb (eds). 2005. Hunter-Gatherer Childhoods: Evolutionary, Developmental and Cultural Perspectives. New Brunswick: Transaction Publishers.

Hiatt, L.R. 1962. 'Local organization among the Australian Aborigines'. Oceania 32(4): 267-86. doi.org/10.1002/j.1834-4461.1962.tb01782.x

Hill, Kim and A. Magdalena Hurtado. 1996. Ache Life History: The Ecology and Demography of a Foraging People. New York: Aldine de Gruyter.

Hilton, Charles E. and Russell D. Greaves. 2004. 'Age, sex, and resource transport in Venezuelan foragers'. In From Biped to Strider: The Emergence of Modern Human Walking, Running, and Resource Transport, edited by D. Jeffrey Meldrum and Charles E. Hilton, 163-81. New York: Kluwer. doi.org/10.1007/978-1-4419-8965-9_10

- 2008. 'Seasonality and sex differences in travel distance and resource transport in Venezuelan foragers'. Current Anthropology 49(1): 144-53. doi.org/10.1086/524760

Hohmann, Gottfried, Martha Robbins and Christophe Boesch (eds). 2006. Feeding Ecology in Apes and Other Primates. Cambridge: Cambridge University Press.

Honigmann, John J. (ed.). 1973. Handbook of Social and Cultural Anthropology. Chicago: Rand McNally.

Howell, Nancy. 2001. Demography of the Dobe !Kung. 2nd edition. New York: Aldine de Gruyter.

Hrdy, Sarah Blaffer. 2005. 'Comes the child before the man: How cooperative breeding and prolonged postweaning dependence shaped human potential'. In Hunter Gatherer Childhoods: Evolutionary Developments and Cultural Perspectives, edited by Barry S. Hewlett and Michael E. Lamb, 65-91. New Brunswick: Transaction Publishers.

INE (Instituto Nacional de Estadística-Apure). 2001. Censo comunidades indigenas, pobalción indigena empadronada por grupo segun sexo y pueblo indigena de pertenencia el el esatdo Apure. Online: www.portala pure.com/INDIGENAS.html (accessed 16 January 2005, no longer available). 
2011. Censo nacional de pobalción y vivienda. Empadronamiento de la pobalción indígena. República Bolivariana de Venezuela, Ministerio del Poder Popular de Planificación, Instituto Nacional de Estadística (INE), Gerencia General de Estadísticas Demográficas, Gerencia de Censo de Pobalción y Vivienda. Online: www.ine.gov.ve/index. php?option=com_content\&view=category\&id=95\&Itemid (accessed 14 July 2017).

Kan, Sergei. 1989. Symbolic Immortality: The Tlingit Potlatch of the Nineteenth Century. Washington, DC: Smithsonian Institution Press.

Kaplan, Hillard. 1996. 'A theory of fertility and parental investment in traditional and modern human societies'. Yearbook of Physical Anthropology 39: 91-135. doi.org/10.1002/(SICI) 1096-8644(1996) 23+<91::AID-AJPA4>3.0.CO;2-C

Kelly, Robert L. 1995. The Foraging Spectrum: Diversity in Hunter-Gatherer Lifeways. Washington, DC: Smithsonian Institution Press.

Kensinger, Kenneth M. (ed.). 1984. Marriage Practices in Lowland South America. Urbana: University of Illinois Press.

Kent, Susan (ed.). 1996. Cultural Diversity among Twentieth-Century Foragers: An African Perspective. Cambridge: Cambridge University Press.

Key, Marie Ritchie. 1979. The Grouping of South American Indian Languages. Tübingen: Ars Linguistica 2. Gunter Narr Verlag.

Knecht, Heidi (ed.). 1997. Projectile Technology. Interdisciplinary Contributions to Archaeology Series. New York: Plenum Press.

Korotayev, Andrey. 2001. 'An apologia of George Peter Murdock. Discussion of labor by gender and postmatital residence in crosscultural perspective: a reconsideration'. World Cultures 12(2): 179-203.

Kramer, Karen L. 2008. 'Early sexual maturity among Pumé foragers of Venezuela: Fitness implications of teen motherhood'. American Journal of Physical Anthropology 136(3): 338-50. doi.org/10.1002/ajpa.20817

Kramer, Karen L. and Russell D. Greaves. 2007. 'Changing patterns of infant mortality and fertility among Pumé foragers and horticulturalists'. American Anthropologist 109(4): 713-26. doi.org/ 10.1525/aa.2007.109.4.713 
2010. 'Synchrony between growth and reproductive patterns in human females: Early investment in growth among Pumé foragers'. American Journal of Physical Anthropology. 141(2): 235-44. doi.org/ 10.1002/ajpa.21139

2017. 'Why Pumé foragers retain a hunting and gathering way of life'. In Hunter-Gatherers in a Changing World, edited by Victoria Reyes-García and Aili Pyhälä, 109-26. Cham: Springer. doi.org/ 10.1007/978-3-319-422-71-8_7

Kramer, Karen L., Russell D. Greaves and Peter D. Ellison. 2009. 'Early reproductive maturity among Pumé foragers: Implications of a pooled energy model to fast life histories'. American Journal of Human Biology 21(4): 430-37. doi.org/10.1002/ajhb.20930

Kumar, Vikrant, Banrida T. Langstieh, Komal V. Madhavi, Vega M. Naidu, Hardeep Pal Singh, Silpak Biswas, Kumarasamy Thangaraj, Lalji Singh, and B. Mohan Reddy. 2006. 'Global patterns in human mitochondrial DNA and Y-chromosome variation caused by spatial instability of the local cultural processes'. PLoS One 2(4): e53. doi.org/ 10.1371/journal.pgen.0020053

Langergraber, Kevin E., Heike Siedel, John C. Mitani, Richard W. Wrangham, Vernon Reynolds, Kevin Hunt and Linda Vigilant 2007. 'The genetic signatures of sex-biased migration in patrilocal chimpanzees and humans'. PLoS One 2(10):e973. doi.org/10.1371/ journal.pone.0000973

Layrisse, Miguel, Zulay Layrisse, E. Garcia and Johannes Wilbert. 1961. 'Blood group antigen tests groups of the Yaruro Indians'. Southwestern Journal of Anthropology 17(2):198-204. doi.org/10.1086/ soutjanth.17.2.3629143

Layrisse, Miguel, Zulay Layrisse and Johannes Wilbert. 1964. 'Variaciones genéticas de grupos sanguíneos en 12 tribus de Caribes en Venezuela y Guayana Británica'. Actas y Memorias del 25 Congeso Internacional de Americanistas 3: 49-55.

Lee, Richard B. 1972. 'Work effort, group structure, and land-use in contemporary hunter-gatherers'. In Man, Settlement, and Urbanism, edited by Peter J. Ucko, Ruth Tringham and G.W. Dimbelby, 177-85. London: Gerald Duckworth. 
- 1976. '!Kung spatial organization: An ecological and historical model'. In Kalahari Hunter-Gatherers: Studies of the !Kung San and Their Neighbors, edited by Richard B. Lee and Irven DeVore, 73-97. Cambridge: Harvard University Press. doi.org/10.4159/harvard. $9780674430600 . c 6$

- 1979. The!Kung San: Men, Women, and Work in a Foraging Society. Cambridge: Cambridge University Press.

Lee, Richard B. and Irven DeVore. 1968. 'Problems in the study of hunter-gatherers'. In Man The Hunter: The First Intensive Survey of a Single, Crucial Stage of Human Development-Man's Once Universal Hunting Way of Life, edited by Richard B. Lee and Irven DeVore, 3-12. Chicago: Aldine.

Lee, Richard B. and Irven DeVore (eds). 1976. Kalahari Hunter-Gatherers: Studies of the !Kung San and Their Neighbors. Cambridge: Harvard University Press. doi.org/10.4159/harvard.9780674430600

Leeds, Anthony. 1961. 'The Yaruro incipient tropical forest horticulture: Possibilities and limits'. In The Evolution of Horticultural Systems in Native South America: Causes and Consequences, edited by Johannes Wilbert, 13-46. Antropológica Supplement no. 2. Caracas: Editorial Sucre.

- 1964. 'Some problems of Yaruro ethnohistory'. Actas y Memorias del 25 Congreso International de Americanistas 2: 157-75.

Lévi-Strauss, Claude. 1949. Les Structures élémentaires de la parenté. Paris: Presses Universitaire de France.

Lizarralde, Roberto and Ted Gragson, unpublished data; portions published in OCEI 1985 and 1995.

Lizot, Jacques (ed.). 1988. Los Aborigenes de Venezuela, Vol. III, Etnología Contemporánea II. Caracas: Fundación La Salle de Ciencias Naturales.

Loukotka, Čestmír and Johannes Wilbert. 1968. Classification of South American Indian Languages. Reference Series vol. 7. Los Angeles: Latin American Center, University of California.

Lowie, Robert H. 1920. Primitive Society. New York: Boni and Liveright.

Marlowe, Frank W. 2004. 'Marital residence among foragers'. Current Anthropology 45(2): 277-84. doi.org/10.1086/382256 
—_. 2005. 'Hunter-gatherers and human evolution'. Evolutionary Anthropology 14(2): 54-67. doi.org/10.1002/evan.20046

—_. 2006. 'Central place provisioning: The Hadza as an example'. In Feeding Ecology in Apes and Other Primates, edited by Gottfried Hohmann, Martha Robbins and Christophe Boesch, 359-77. Cambridge: Cambridge University Press.

—_. 2010. The Hadza: Hunter-Gatherers of Tanzania. Berkeley: University of California Press.

Marshall, Lorna. 1960. '!Kung Bushman bands'. Africa 30(4): 325-55. doi.org/10.2307/1157596

—_. 1976. The !Kung of Nyae Nyae. Cambridge: Harvard University Press. doi.org/10.4159/harvard.9780674180574

Mauss, Marcel. 1967. The Gift: The Form and Reason for Exchange in Archaic Societies, translated by I. Cunnison. New York: Norton.

Meggitt, M.J. 1965. 'Marriage among the Walbiri of Central Australia: A statistical examination'. In Aboriginal Man in Australia, edited by R.M. Berndt and C.H. Berndt, 146-66. Sydney: Angus and Robertson.

Meldrum, D. Jeffrey and Charles E. Hilton (eds). 2004. From Biped to Strider: The Emergence of Modern Human Walking, Running, and Resource Transport. New York: Kluwer. doi.org/10.1007/978-1-44198965-9

Mitrani, Philippe. 1975. Remarques sur l'organisation sociale, la parenté et l'alliance des Yaruro de l'Apure. Antropológica 40: 3-23.

—_. 1988. 'Los Pumé (Yaruro)'. In Los Aborigenes de Venezuela, Vol. III, Etnología Contemporánea II, edited by Jacques Lizot, 147-213. Caracas: Fundación La Salle de Ciencias Naturales.

Mosonyi, Esteban Emelio. 1975. El Indígena Venezolano en Pos de su Liberación Definitiva. Cracas: Universidad Central de Venezuela, Facultad de Ciencias Económicas y Sociales, División de Publicaciónes.

Murdock, George Peter. 1949. Social Structure. New York: Macmillan. 
Murdock, George Peter and Douglas R. White. 1980. 'Standard crosscultural sample'. In Cross-Cultural Sample and Codes, edited by Herbert Barry and Alice Schlegel, 3-43. Pittsburgh: University of Pittsburgh Press.

Needham, Roger. 1954. 'The system of teknonyms and death names of the Penan'. Southwestern Journal of Anthropology 10(4): 416-31. doi.org/10.1086/soutjanth.10.4.3628836

Oberg, Kalvero. 1973. The Social Economy of the Tlingit Indians. American Ethnological Society Monograph 55. Seattle: University of Washington Press.

Obregón Muñoz, Hugo. 1981. 'En torno al alfabeto de las lenguas indígenas de Venezuela a propósito de la reducción del Pumé a la escritura'. Revista Latinoamericana de Estudios Etnolingüisticos 1:25-46.

OCEI ( Oficina Central de Estadística e Informática). 1985. Censo Indigena de Venezuela. Caracas: Taller Gráfico de la Oficina Central de Estadística e Informática.

- 1995. Censo Indígena de Venezuela 1992. Tomo I. Caracas: Taller Gráfico de la Oficina Central de Estadística e Informática.

Oota, H., W. Settheetham-Ishida, D. Tiwawech, I. Takfumi and M. Stoneking. 2001. 'Human mtDNA and Y-chromosome variation is correlated with matrilocal versus patrilocal residence'. Nature Genetics 29(1): 20-21. doi.org/10.1038/ng711

Orobitg Canal, Gemma. 1998. Les Pumé et Leurs Rêves: Êtude d'un Groupe Indien des Plaines du Venezuela. Amsterdam: Éditions des Archies Contemporaines.

Otterbein, Keith F. and Frank W. Marlowe. 2005. 'On hunting and virilocality'. Current Anthropology 46(1): 124-27. doi.org/10.1086/ 427097

Panter-Brick, Catherine, Robert Layton and Peter Rowley-Conwy (eds). 2001. Hunter-Gatherers: An Interdisciplinary Approach. Cambridge: Cambridge University Press.

Perez de Vega, F. 1960. Las lenguas aborigenes. Caracas: Editorial Ciencia.

Perry, Richard J. 1989. 'Matrilineal descent in a hunting context: The Athapaskan case'. Ethnology 28(1): 33-51. doi.org/10.2307/3773641 
Petrullo, Vincenzo. 1939. The Yaruros of the Capanaparo River, Venezuela. Anthropological Papers 11, Bureau of American Ethnology Bulletin 123: 161-290. Washington, DC: Smithsonian Institution.

Quinlan, Robert J. and Marsha B. Quinlan. 2007. 'Evolutionary ecology of human pair bonds: cross-cultural tests of alternative hypotheses'. Cross-Cultural Research 41(2): 149-69. doi.org/10.1177/ 1069397106298893

Radcliffe-Brown, A.R. 1930. 'The social organization of Australian tribes'. Oceania 1(2): 206-46. doi.org/10.1002/j.1834-4461.1930.tb01645.x

Reining, Priscilla (ed.). 1972. Kinship Studies in the Morgan Centennial Year. Washington: Anthropological Society of Washington.

Rey Fajardo, José del. 1979. 'Los Jesuitas y las lenguas Indígenas Venezolanas'. Montalban 9: 357-478.

Reyes-García, Victoria and Aili Pyhälä (eds). 2017. Hunter-Gatherers in a Changing World. Cham: Springer. doi.org/10.1007/978-3-31942271-8

Richerson, Peter J. and Robert Boyd. 2008. 'Cultural evolution: Accomplishments and future prospects'. In Explaining Culture Scientifically, edited by Melissa J. Brown, 75-99. Seattle: University of Washington Press.

Rodseth, Lars, Richard W. Wrangham, Alisa M. Harrigan, Barbara B. Smuts, Ron Dare, Robin Fox, Barbara J. King, P. C. Lee, R. A. Foley, J. C. Muller, Keith F. Otterbein, Karen B. Strier, Paul W. Turke and Milford H. Wolpoff. 1991. 'The human community as a primate society'. Current Anthropology32(3):221-54. doi.org/10.1086/203952

Ruvolo, M. 1997. 'Genetic diversity in hominoid primates'. Annual Review of Anthropology 26: 515-40. doi.org/10.1146/annurev.anthro. 26.1.515

Salmon, Catherine A. and Todd K. Shackelford (eds). 2007. Family Relationships: An Evolutionary Perspective. New York: Oxford University Press. doi.org/10.1093/acprof:oso/9780195320510.001.0001

SAS. 2002-2003. Cary, NC: SAS Institute, Inc. 
Scelza, Brook and Rebecca Bliege Bird. 2008. 'Group structure and female cooperative networks in Australia's Western Desert'. Human Nature 19: 231-48. doi.org/10.1007/s12110-008-9041-5

Scheffler, Harold W. 1965. Choiseul Island Social Structure. Berkeley: University of California Press.

- 1970. 'Kinship and adoption in the northern New Hebrides'. In Adoption in Eastern Oceania, edited by Vern Carroll, 369-89. Honolulu: University of Hawaii Press.

— 1972. 'Baniata kin classification: The case for extensions'. Southwestern Journal of Anthropology 28(4): 350-81. doi.org/10.1086/ soutjanth.28.4.3629317

- 1973. 'Kinship, descent, and alliance'. In Handbook of Social and Cultural Anthropology, edited by John J. Honigmann, 747-93. Chicago: Rand McNally.

—. 2001. Filiation and Affliation. Boulder, CO: Westview Press.

Schneider, David M. 1972. 'What is kinship all about?' In Kinship Studies in the Morgan Centennial Year, edited by Priscilla Reining, 32-63. Washington: Anthropological Society of Washington.

- 1984. A Critique of the Study of Kinship. Ann Arbor: University of Michigan Press. doi.org/10.3998/mpub.7203

Seielstad, Mark, Eric Minch and L. Luca Cavalli-Sforza. 1998. 'Genetic evidence for a higher female migration rate in humans'. Nature Genetics 20(3): 278-80. doi.org/10.1038/3088

Sellet, Frederic, Russell D. Greaves and Pei-Lin Yu (eds). 2006. Archaeology and Ethnoarchaeology of Mobility. Gainesville: University Press of Florida.

Service, Elman R. 1962. Primitive Social Organization: An Evolutionary Perspective. New York: Random House.

—. 1966. The Hunters. Engelwood Cliffs: Prentice Hall.

Shapiro, Judith R. 1984. 'Marriage rules, marriage exchange, and the definition of marriage in lowland South American socieites'. In Marriage Practices in Lowland South America, edited by Kenneth M. Kensinger, 1-30. Urbana: University of Illinois Press. 
Shapiro, Warren. 1973. 'Residential grouping in northeast Arnhem Land'. Man (n.s.) 8(3): 365-83. doi.org/10.2307/2800315

—_. 1995. 'Fuzziness, structure-dependency, and "structural anthropology": An extended reply to Parkin'. Journal of the Anthropological Society of Oxford 26(2): 197-214.

—_. 2008. 'What human kinship is primarily about: Toward a critique of the new kinship studies'. Social Anthropology 16(2): 137-53. doi.org/10.1111/j.1469-8676.2008.00038.x

Shrire, Carmel (ed.). 1984. Past and Present in Hunter-Gatherer Studies. New York: Academic Press.

Silberbauer, George B. 1972. 'The G/wi bushmen'. In Hunters and Gatherers Today: A Socioeconomic Study of Eleven Such Cultures in the Twentieth Century, edited by M.G. Bicchieri, 271-326. New York: Holt, Rinehart and Winston.

Smith, Eric Alden. (1991). Inujjuamiut Foraging Strategies: Evolutionary Ecology of an Arctic Hunting Economy. New York: Aldine de Gruyter.

Steward, Julian Haynes. 1955. Theory of Culture Change: The Methodology of Multilinear Evolution. Urbana: University of Illinois Press.

Tierney, Patrick. 2000. Darkness in El Dorado: How Scientists and Journalists Devastated the Amazon. New York: Norton.

Tovar, Antonio and Consuelo Larrucea de Tovar. 1961. Catálogo de las Lenguas de América del Sur. Buenos Aires: Editorial Sudamericana.

Turnbull, Colin M. 1965. Wayward Servants: The Two Worlds of African Pygmies. Westport: Greenwood Press.

Ucko, Peter J., Ruth Tringham and G.W. Dimbelby (eds). 1972. Man, Settlement, and Urbanism. London: Gerald Duckworth.

Walker, Robert S., Stephen Beckerman, Mark V. Flinn, Michael Gurven, Chris R. von Rueden, Karen L. Kramer, Russell D. Greaves, Lorena Córdoba, Diego Villar, Edward H. Hagen, Jeremy M. Koster, Lawrence Sugiyama, Tiffany E. Hunter and Kim R. Hill. 2013. 'Living with kin in lowland horticultural societies'. Current Anthropology 54(1): 96-103. doi.org/10.1086/668867 
Wiessner, Polly. 2002. 'Hunting, healing, and hxaro exchange: A longterm perspective on !Kung (Ju/'hoansi) large game hunting'. Evolution and Human Behavior 23(6): 407-36. doi.org/10.1016/S1090-5138 (02)00096-X

Wilbert, Johannes (ed.). 1961. The Evolution of Horticultural Systems in Native South America: Causes and Consequences. Antropológica Supplement no. 2. Caracas: Editorial Sucre.

Wilder, Jason A., Sarah B. Kingan, Zahra Mobasher, Maya Metni Pilkington and Michael F. Hamme. 2004. 'Global patterns of human mitochondrial DNA and Y-chromosome structure are not influenced by higher migration rates of females versus males'. Nature Genetics 36: 1122-25. doi.org/10.1038/ng1428

Wilmsen, Edwin N. 1989. Land Filled with Flies: A Political Economy of the Kalahari. Chicago: University of Chicago Press.

Winterhalder, Bruce and Eric A. Smith (eds). 1981. Hunter-Gatherer Foraging Strategies. Chicago: University of Chicago Press.

Wolf, Arthur P. and William H. Durham (eds). 2004. Inbreeding, Incest, and the Incest Taboo: The State of Knowledge at the Turn of the Century. Stanford: Stanford University Press.

Wood, Brian M. and Frank W. Marlowe. 2011. 'Dynamics of postmarital residence among the Hadza: A kin investment model'. Human Nature 22(1-2): 128-38. doi.org/10.1007/s12110-011-9109-5

Woodburn, James. 1968. 'Stability and flexibility in Hadza residential groupings'. In Man The Hunter: The First Intensive Survey of a Single, Crucial Stage of Human Development-Man's Once Universal Hunting Way of Life, edited by Richard B. Lee and Irven DeVore, 103-17. Chicago: Aldine.

1972. 'Ecology, nomadic movement and the composition of the local group among hunters and gatherers: An East African example and its implications'. In Man, Settlement and Urbanism, edited by Peter J. Ucko, Ruth Tringham and G.W. Dimbelby, 193-206. London: Gerald Duckworth. 
This text is taken from Focality and Extension in Kinship: Essays in Memory of Harold W. Scheffler, edited by Warren Shapiro, published 2018 by ANU Press, The Australian National University, Canberra, Australia.

doi.org/10.22459/FEK.04.2018.04 